\title{
Viability of one-cell bovine embryos cultured in vitro: comparison of cell-free culture with co-culture
}

\author{
K. Goto, N. Iwai, K. Ide, Y. Takuma and Y. Nakanishi \\ Laboratory of Animal Reproduction, Faculty of Agriculture, Kagoshima University, Kagoshima, \\ 890 Japan
}

\begin{abstract}
In this study, the quality (number of cells) and pregnancy rates of bovine blastocysts produced by in vitro maturation/in vitro fertilization (IVM/IVF) following cultivation in either cell-free culture or co-culture were compared. Bovine one-cell IVM/IVF embryos obtained $6 \mathrm{~h}$ after insemination were stripped of cumulus cells and assigned to either cell-free culture or co-culture with granulosa cell monolayers for 9 days (Expt 1) or 10 days (Expts 2 and 3). In Expt 3, day-7 (day $0=$ day of insemination) blastocysts, day-8 expanded blastocysts and day-9 hatched blastocysts were air-dried, fixed and stained to determine the number of cells. Expanded blastocysts obtained in Expt 1 were cryopreserved using propylene glycol as a cryoprotectant and were used later for embryo transfer. There were no significant differences between cell-free culture and co-culture in the percentage of one-cell embryos that developed to 2 - to 16 -cells $(66.7 \%$ versus $72.4 \%$ for Expt $1,71.0 \%$ versus $78.2 \%$ for Expt 2$)$. However, significantly more $(P<0.05)$ of the one-cell embryos co-cultured with granulosa cell monolayers developed to morula, blastocyst and expanded blastocyst stages compared with those in cell-free culture $(35.0$ versus $27.1 \%, 25.1$ versus $14.2 \%, 15.6$ versus $5.4 \%$ for Expt $1 ; 37.6$ versus $24.0 \%, 25.7$ versus $11.0 \%$, 16.8 versus $3.0 \%$ for Expt 2). Only embryos co-cultured with granulosa cell monolayers hatched (Expt 2). Embryos co-cultured with granulosa cell monolayers also had higher $(P<0.01)$ numbers of cells $(92 \pm 42$ versus $56 \pm 21$ for blastocysts, $149 \pm 53$ versus $81 \pm 29$ for expanded blastocysts). Pregnancy rates tended to be higher for embryos produced by co-culture compared with those from cell-free culture ( 40.0 versus $27.3 \%$, respectively). The results suggest that embryos produced in cell-free culture were of poorer quality than those produced in co-culture; however, some of them were developmentally competent as confirmed by the births of three calves after transfer to eleven recipient cows.
\end{abstract}

\section{Introduction}

The biochemical requirements for normal, in vitro development of early preimplantation embryos of domestic animals have not been defined (Rexroad, 1989). Somatic cell co-culture is one method for overcoming the in vitro developmental block of cultured mammalian embryos. However, the ideal culture system should exclude co-culture with somatic cells or supplementation with serum because neither of these systems are chemically defined. The somatic cells used for co-culture may produce unknown, embryo growth promoting factor(s) and/or delete embryo-toxic factor(s) from the culture medium (Eyestone and First, 1989), making it difficult to determine the exact requirements for embryo development, and preventing a clear understanding of embryo metabolism, independent of other cell types. A successful embryo culture system using a medium free of somatic cells is needed for the in vitro study of

Received 26 April 1993 embryo development. Such a system for in vitro matured/in vitro fertilized (IVM/IVF) bovine embryos has been developed by several workers (Fukui et al., 1991; Rosenkrans and First, 1991; Pinyopummintr and Bavister, 1991; Takahashi and First, 1992); however, the viability of blastocysts produced by their system has not been examined following embryo transfer. Larson et al. (1992) and Goto et al. (1992) succeeded in obtaining calves following the transfer of IVM/IVF bovine embryos developed in a cell-free culture system. However, the latter study showed that the viability, as assessed by embryo transfer, of IVM/IVF bovine embryos produced in the cell-free system was lower than that of embryos produced in the co-culture system.

The objective of this study was to compare the quality and pregnancy rate of blastocysts produced by either cell-free culture or co-culture systems directly. Blastocyst quality was assessed in vitro by the number of cells per blastocyst and development to hatched blastocyst and in vivo viability was determined after transfer to recipient cows. 


\section{Materials and Methods}

In vitro maturation and fertilization of ovarian oocytes

The method for the production of IVM/IVF zygotes was a modification of the procedure of Goto et al. (1988). Briefly, cumulus-oocyte complexes were aspirated from small ( $1-7 \mathrm{~mm}$ in diameter) antral follicles on bovine ovaries obtained from an abattoir. They were washed three times with Whittingham's modified Dulbecco's phosphate-buffered saline (mPBS; Whittingham, 1971) supplemented with $1 \%$ newborn calf serum (CS; Gibco, New York), followed by one wash with maturation medium. The maturation medium was $12.5 \mathrm{mmol}$ Hepes TCM $199 \mathrm{1}^{-1}$ (Gibco) supplemented with 5\% calf serum. Only oocytes with an intact, non-expanded cumulus mass and evenly granulated cytoplasm (60-90 cumulus-oocyte complexes per $2.5 \mathrm{ml}$ medium) were then cultured for the $22 \mathrm{~h}$ maturation.

In vitro fertilization was performed using frozen semen from a single ejaculate from one bull. The frozen-thawed semen $(0.5 \mathrm{ml})$ was diluted with $\mathrm{BO}$ medium (Brackett and Oliphant, 1975) without BSA but with caffeine $\left(5 \mathrm{mmol} \mathrm{l}^{-1}\right)$ and heparin $\left(60 \mu \mathrm{g} \mathrm{ml}^{-1}\right)$. The spermatozoa were washed with this medium $(8 \mathrm{ml})$ twice, by centrifugation at $700 \mathrm{~g}$ for $7 \mathrm{~min}$. The spermatozoa were then resuspended to a concentration of $5 \times 10^{6}$ cells ml ${ }^{-1}$ and were preincubated for $2 \mathrm{~h}$ in BO medium supplemented with $2.5 \mathrm{mmol}$ caffeine $\mathrm{I}^{-1}, 30 \mu \mathrm{g}$ heparin $\mathrm{ml}^{-1}$ and $5 \mathrm{mg} \mathrm{BSA} \mathrm{ml}{ }^{-1}$. In vitro fertilization was conducted by co-incubating spermatozoa $\left(5 \times 10^{6}{\left.\text { cells } \mathrm{ml}^{-1}\right)}^{-1}\right.$ and cumulus-oocyte complexes (15-20 per $110 \mu \mathrm{l}$ drop) for $6 \mathrm{~h}$.

\section{Preparation of granulosa cell monolayers}

Granulosa cell monolayers were prepared from granulosa cells aspirated from bovine follicles using established methods (Goto et al., 1990). Briefly, follicular fluid containing granulosa cells was centrifuged ( $180 \mathrm{~g}$ for $5 \mathrm{~min}$ ). The pellet of granulosa cells was washed by centrifugation at $180 \mathrm{~g}$ for $5 \mathrm{~min}$ in $5 \mathrm{ml}$ of $\mathrm{mPBS}$ supplemented with $1 \%$ calf serum. The pellet was suspended in $1 \mathrm{ml}$ of an enzyme solution containing $1000 \mathrm{U}$ protease $\mathrm{ml}^{-1}$ (Dispase: Sanko Junyaku, Tokyo). Cells were incubated for $20-40 \mathrm{~min}$ at $38.7^{\circ} \mathrm{C}$. The cells were then vigorously pipetted to permit the separation of cells, followed by three washings ( $180 \mathrm{~g}$ for $5 \mathrm{~min}$ ) in mPBS. After the final washing, $5 \mathrm{ml}$ of maturation medium (12.5 mmol Hepes TCM $199+5 \%$ calf serum) was added to the cells, and the cell suspension was passed through a wire mesh to remove large cell clumps. Aliquots of cell suspension $\left(2.5 \mathrm{ml}, 10^{5}\right.$ cells ml $^{-1}$ of culture medium) were placed in each culture dish ( $35 \mathrm{M} / \mathrm{M}$; Termo, Tokyo) so that $80-100 \%$ confluence would be attained within $48 \mathrm{~h}$. The percentage of live cells was over $80 \%$ at the beginning of culture.

\section{In vitro culture of one-cell embryos}

One-cell embryos were stripped of cumulus cells after co-incubation with spermatozoa by vortexing in TCM 199 supplemented with $0.1 \%$ hyaluronidase. The embryos were then washed three times with development medium (12.5 mmol Hepes TCM $199+1 \%$ calf serum $+1 \mathrm{mmol}$ sodium pyruvate $1^{-1}$ ). The cumulus-free one-cell embryos (30-45 embryos per $2.5 \mathrm{ml}$ culture medium) were randomly assigned to either cell-free culture or co-culture with granulosa cell monolayers for 9 days (Expt 1 ) or 10 days (Expts 2 and 3). Developmental stages of embryos were examined every $24 \mathrm{~h}$. The development medium was replaced with new medium every $48 \mathrm{~h}$. All of the culture media used were supplemented with antibiotics (100 IU penicillin $\mathrm{ml}^{-1}$ and $100 \mu \mathrm{g}$ streptomycin $\mathrm{ml}^{-1}$ ). All cultures were maintained at $38.7^{\circ} \mathrm{C}$ in a humidified atmosphere of $5 \% \mathrm{CO}_{2}$ in air.

\section{Evaluation of number of cells per embryo}

In Expt 3, day 7 (day $0=$ day of insemination) blastocysts, day 8 expanded blastocysts and day- 9 hatched blastocysts were air-dried and the number of cells counted (Tokumaru et al., 1989). Briefly, the embryos were treated with a hypotonic solution $(0.5 \%$ sodium citrate) and then fixed with acetic acid:methanol (1:3). After staining with 5\% Giemsa solution, the total number of cells were counted under a microscope.

\section{Cryopreservation and embryo transfer}

Expanded blastocysts from Expt 1 obtained 8 days after insemination from either cell-free culture or co-culture were equilibrated in a three-step procedure with $0.5 \mathrm{~mol}$ propylene glycol $1^{-1}$ for $5 \mathrm{~min}, 1.0 \mathrm{~mol}$ propylene glycol $\mathrm{l}^{-1}$ for $5 \mathrm{~min}$ and $1.6 \mathrm{~mol}$ propylene glycol $^{-1}$ for $10-15 \mathrm{~min}$ in a base medium of mPBS supplemented with $20 \%$ calf serum. Embryos in the $1.6 \mathrm{~mol}$ propylene glycol $\mathrm{I}^{-1}$ were loaded into straws (one embryo per straw) and were separated by two air bubbles from the medium $\left(0.2 \mathrm{~mol}\right.$ sucrose $\mathrm{I}^{-1}$ with $20 \%$ calf serum in $\mathrm{mPBS}$ ) filling the remainder of the straw. Straws were placed directly into a cooling chamber (ET-1, Fujihira, Tokyo) kept at $0^{\circ} \mathrm{C}$ and cooled to $-6^{\circ} \mathrm{C}$ at $-1^{\circ} \mathrm{C} \mathrm{min}{ }^{-1}$. After holding for $10 \mathrm{~min}$ at this temperature, including time for seeding, the straws were cooled to $-30^{\circ} \mathrm{C}$ at $-0.3^{\circ} \mathrm{C} \min ^{-1}$. The straws were held for $10 \mathrm{~min}$ at this temperature before being plunged into liquid nitrogen. Straws were thawed at $30^{\circ} \mathrm{C}$ in water and the embryos were directly transferred into recipient cows (7-8 days after standing oestrus; one embryo per recipient).

\section{Pregnancy diagnosis}

Pregnancy diagnosis was made by ultrasound $40-42$ days after embryo transfer.

\section{Statistical analysis}

Chi-square test was used to examine differences in developmental rates between the two culture groups. The total number of cells in blastocysts was subjected to logarithmic transformation before being subjected to analysis of variance. Mean differences were determined by Student's $t$ test. Pregnancy 
Table 1. In vitro development of bovine one-cell embryos cultured for 9 days in cell-free culture or co-culture systems

\begin{tabular}{|c|c|c|c|c|c|}
\hline \multirow[b]{2}{*}{ Culture system } & \multirow[b]{2}{*}{ Number of one-cell embryos* } & \multicolumn{4}{|c|}{ Number (\%) of embryos developed to: } \\
\hline & & $\begin{array}{l}\text { 2- to 16-cell } \\
\text { (day 2-3) }\end{array}$ & $\begin{array}{c}\text { Morula } \\
(\text { day 4-6) }\end{array}$ & $\begin{array}{l}\text { Blastocyst } \\
\text { (day 6-8) }\end{array}$ & $\begin{array}{c}\text { Expanded blastocyst } \\
\text { (day 7-9) }\end{array}$ \\
\hline Cell-free & 240 & $160(66.7)^{\mathrm{a}}$ & $64(27.1)^{a}$ & $34(14.2)^{\mathrm{a}}$ & $13(5.4)^{\mathrm{a}}$ \\
\hline Co-culture & 243 & $176(72.4)^{\mathrm{a}}$ & $85(35.0)^{\mathrm{b}}$ & $61(25.1)^{\mathrm{b}}$ & $38(15.6)^{b}$ \\
\hline
\end{tabular}

*Total from six replicates.

${ }^{\mathrm{ab}}$ Means within a column with different superscripts are significantly different $(P<0.05)$.

Table 2. In vitro development of bovine one-cell embryos cultured for 10 days in cell-free culture or co-culture systems

\begin{tabular}{|c|c|c|c|c|c|c|}
\hline \multirow[b]{2}{*}{ Culture system } & \multirow[b]{2}{*}{ Number of one-cell embryos* } & \multicolumn{5}{|c|}{ Number $(\%)$ of embryos developed to: } \\
\hline & & $\begin{array}{l}\text { 2- to } 16 \text {-cell } \\
\text { (day 2-3) }\end{array}$ & $\begin{array}{l}\text { Morula } \\
\text { (day 4-6) }\end{array}$ & $\begin{array}{l}\text { Blastocyst } \\
\text { (day 6-8) }\end{array}$ & $\begin{array}{c}\text { Expanded blastocyst } \\
\text { (day 7-9) }\end{array}$ & $\begin{array}{l}\text { Hatched blastocyst } \\
\text { (day 8-10) }\end{array}$ \\
\hline Cell-free & 100 & $71(71.0)^{a}$ & $24(24.0)^{\mathrm{a}}$ & $11(11.0)^{\mathrm{a}}$ & $3(3.0)^{\mathrm{a}}$ & $0(0)^{a}$ \\
\hline Co-culture & 101 & $79(78.2)^{a}$ & $38(37.6)^{b}$ & $26(25.7)^{\mathrm{b}}$ & $17(16.8)^{b}$ & $11(10.9)^{b}$ \\
\hline
\end{tabular}

*Total from three replicates.

${ }^{\mathrm{ab}}$ Means within a column with different superscripts are significantly different $(P<0.05)$.

Table 3. Number of cells of IVM/IVF* blastocysts produced in cell-free culture or co-culture systems

\begin{tabular}{lccc}
\hline & \multicolumn{3}{c}{ Stage of embryo } \\
\cline { 2 - 4 } Culture system & $\begin{array}{c}\text { Blastocyst } \\
\text { (day 7) }\end{array}$ & $\begin{array}{c}\text { Expanded blastocyst } \\
(\text { day } 8)\end{array}$ & $\begin{array}{c}\text { Hatched blastocyst } \\
\text { (day 9) }\end{array}$ \\
\hline Cell-free & $56 \pm 21^{\mathrm{a}}$ & $81 \pm 29^{\mathrm{a}}$ & None \\
Co-culture & $(30)$ & $(27)$ & $($ None) \\
& $92 \pm 42^{\mathrm{b}}$ & $149 \pm 53^{\mathrm{b}}$ & $189 \pm 60$ \\
\end{tabular}

Values are means \pm SD. Number of embryos examined in parentheses.

${ }^{\mathrm{ab}}$ Means within a column with different superscripts are significantly different $(P<0.01)$.

*IVM: in vitro maturation; IVF; in vitro fertilization.

rates were compared using a $\chi^{2}$ test incorporating Yates' continuity correction.

\section{Results}

There was no significant difference in the percentage of one-cell embryos that developed to the 2- to 16-cell stage in cell-free culture and co-culture $(66.7$ and $72.4 \%$, respectively; Table 1). However, one-cell embryos co-cultured with granulosa cell monolayers showed significantly higher development $(P<0.05)$ to morula, blastocyst and expanded blastocyst stages than did those of cell-free culture (35.0 versus $27.1 \%, 25.1$ versus $14.2 \%$, 15.6 versus $5.4 \%$, respectively). Similar results were obtained in Expt 2 (Table 2). Only embryos co-cultured with granulosa cell monolayers hatched from their zonae pellucidae (Table 2).
The mean number of cells in blastocysts and expanded blastocysts derived from cell-free culture (56 and 81, respectively) was lower (Table $3, P<0.01$ ) than those obtained from co-culture (92 and 149, respectively). The mean number of cells in hatched blastocysts (co-culture only) was 189.

Pregnancy rate after the transfer of frozen-thawed IVM/ IVF/IVC embryos was 27.3 and $40.0 \%$ for cell-free culture and co-culture, respectively (Table 4). However, the difference was not significant $(P>0.05)$ owing to the limited number of embryo transfers.

Three calves were born to eleven recipient cows that received embryos produced in cell-free culture, whereas five calves were bom to fifteen recipient cows that received embryos produced in co-culture. One pregnancy in the co-culture group was lost at four months gestation. 
Table 4. Effect of culture system on pregnancy rate of frozen-thawed IVM/IVF* bovine embryos

\begin{tabular}{lcccc}
\hline Culture system & Number of embryos transferred & Number of pregnancies & Pregnancy rate (\%)** & Number of calves born \\
\hline Cell-free & 11 & 3 & 27.3 & 3 \\
Co-culture & 15 & 6 & 40.0 & $5^{\text {a }}$ \\
\hline
\end{tabular}

*IVM: in vitro maturation; IVF: in vitro fertilization.

**No significant difference $(P>0.05)$ between culture systems.

${ }^{a}$ One pregnancy was lost at 4 months gestation.

\section{Discussion}

This study demonstrates that a cell-free culture system containing calf serum can be used to culture IVM/IVF bovine embryos to the blastocyst stage. However, developmental rate and quality of blastocysts produced in cell-free culture were poorer than those obtained following co-culture. The contribution(s) made by somatic cells to the in vitro development of bovine embryos may fall into one of four categories: (1) production of factors that stimulate embryo development (Gandolfi and Moor, 1987; Heyman et al., 1987; Eyestone and First, 1989; Moor et al., 1990); (2) removal of inhibitory compounds present in the culture environment (Carney et al., 1990; Bavister ef al., 1992); (3) reduction of oxygen concentration (Tervit et al., 1972; Wright et al., 1976; Thompson et al., 1990; Fukui et al., 1991; Voelkel and Hu, 1992); or (4) physical contact between the embryo and the somatic cells (Kuzan and Wright, 1982; Allen and Wright, 1984). In the present study it was not determined which of these mechanisms was responsible for the increased blastocyst quality.

Poor quality embryos produced in cell-free culture have also been reported by Takahashi and First (1992), who used a semi-defined medium containing BSA, and by Larson et al. (1992) who used a chemically defined medium containing growth factors. However, a direct comparison of embryo quality and pregnancy rate between cell-free culture and co-culture was not made in these studies. The results of the present study indicate that embryos produced in cell-free culture were of poorer quality (fewer cells per blastocyst and poorer development beyond morula stage) and possessed poorer in vivo developmental capability (lower pregnancy rate) compared with those produced in co-culture. Moreover, from visual assessment, the development of embryos in cell-free culture was about $0.5-1$ day behind that of co-cultured embryos (data not shown). This is a further indication of the poor quality of embryos produced in cell-free culture, and supports the work of Goto et al. (1992), who reported that the number of cells per bovine blastocyst decreased as the day of blastocoel formation (after IVF) was delayed. A similar observation was reported for rabbit embryos (Fischer and Schumacher, 1991).

Obviously, development of a new culture medium that supports in vitro embryonic development comparable to in vivo is needed. Recent observations (Rieger and Guay, 1988; Butler and Williams, 1991; Tiffin et al., 1991; Rieger et al., 1992) on the metabolism of ovine and bovine embryos may help in designing a better culture medium for supporting embryo development in vitro comparable to that observed in vivo.
These results demonstrate that embryos produced in cellfree culture were of poorer quality than those produced in co-culture. However, some of these embryos are developmentally competent, as confirmed by the birth of three calves after transfer of frozen-thawed blastocysts to recipient cows. Additional improvements in the culture of IVM/IVF embryos should enable the use of this technology, in conjunction with ultrasound-guided transvaginal oocyte retrieval (Pieterse et al., 1991), as part of bovine genetic improvement programmes.

The authors wish to thank C. R. Youngs, lowa State University, for his critical reading of this paper.

\section{References}

Allen RL and Wright RW (1984) In vitro development of porcine embryos in co-culture with endometrial cell monolayers of culture supernatants Journal of Animal Science 59, 1657-1661

Bavister BD, Rose-Hellekant TA and Pinyopummintr T (1992) Development of in vitro matured/in vitro fertilized bovine embryos into morulae and blastocysts in defined culture media Theriogenology 37 127-146

Brackett BG and Oliphant G (1975) Capacitation of rabbit spermatozoa in vitro Biology of Reproduction 12 260-274

Butler JE and Williams JE (1991) Noninvasive measurement of pyruvate uptake by ovine preimplantation embryos and unfertilized ova Theriogenology 36 1043-1048

Carney EW, Tobback C, Ellington JE and Foote RH (1990) Co-culture of rabbit 2 -cell embryos with rabbit oviduct epithelial cells and other somatic cells Molecular Reproduction and Development 27 209-215

Eyestone WH and First NL (1989) Co-culture of early cattle embryos to the blastocyst stage with oviductal tissue or in conditioned medium Journal of Reproduction and Fertility $85715-720$

Fischer B and Schumacher A (1991) Embryonic development and incidence of aneuploidy in two rabbit strains of different fecundity Journal of Reproduction and Fertility $9241-46$

Fukui Y, McGowan LT, James RW, Pugh PA and Tervit HR (1991) Factors affecting the in-vitro development to blastocysts of bovine oocytes matured and fertilized in vitro Journal of Reproduction and Fertility 92 125-131

Gandolfi F and Moor RM (1987) Stimulation of early embryonic development in the sheep by co-culture with oviduct epithelial cells Journal of Reproduction and Fertility 81 23-28

Goto K, Kajihara Y, Kosaka S, Koba M, Nakanishi Y and Ogawa K (1988) Pregnancies after co-culture of cumulus cells with bovine embryos derived from in-vitro fertilization of in-vitro matured follicular oocytes Joumal of Reproduction and Fertility $\mathbf{8 3} 753-758$

Goto K, Kinoshita A, Takuma Y and Ogawa K (1990) Fertilisation of bovine oocytes by the injection of immobilised, killed spermatozoa Veterinary Record 127 517-520

Goto K, Iwai N, Ichikawa K, Ishihara A, Takuma Y, Motoishi M, Tokumaru M and Nakanishi $Y$ (1992) In vitro culture of early bovine embryos produced by in vitro technique Journal of Reproduction and Development 38 165-171

Heyman Y, Menezo Y, Chesne P, Camous S and Garnier V (1987) In vitro cleavage of bovine and ovine early embryos: improved development using co-culture with trophoblastic vesicles Theriogenology $2759-68$ 
Kuzan FG and Wright RW (1982) Observations on the development of bovine morulae on various cellular and non-cellular substrata Journal of Animal Science 54 811-816

Larson RC, Ignotz GG and Currie WB (1992) Transforming growth factor $\beta$ and basic fibroblast growth factor synergistically promote early bovine embryo development during the fourth cell cycle Molecular Reproduction and Development 33 432-435

Moor RM, Nagai T and Gandolfi F (1990) Somatic cell interactions in early mammalian development. In Ovulation to Implantation pp 177-191 Eds JHL Evers and MJ Heineman. Excerpta Medica, Amsterdam

Pieterse MC, Vos PLAM, Kruip ThAM, Wurth YA, van Beneden ThH, Willemse AH and Taverne MAM (1991) Transvaginal ultrasound guided follicular aspiration of bovine oocytes Theriogenology 35 19-24

Pinyopummintr T and Bavister BD (1991) In vitro-matured/in vitro-fertilized bovine oocytes can develop into morulae/blastocysts in chemically defined. protein-free culture medium Biology of Reproduction 45 736-742

Rexroad CE, Jr (1989) Co-culture of domestic animal embryos Theriogenology 31 105-114

Rieger D and Guay P (1988) Measurement of the metabolism of energy substrates in individual bovine blastocysts Joumal of Reproduction and Fertility 83 585-591

Rieger D, Loskutoff NM and Betteridge KJ (1992) Developmentally related changes in the metabolism of glucose and glutamine by cattle embryos produced and co-cultured in vitro Journal of Reproduction and Fertility 95 585-595

Rosenkrans CF, Jr and First NL (1991) Culture of bovine zygotes to the blastocyst stage: effects of amino acids and vitamins Theriogenology 35 Abstract 266
Takahashi $Y$ and First NL (1992) in vitro development of bovine one-cell embryos: influences of glucose, lactate, pyruvate, amino acids and vitamins Theriogenology $37963-978$

Tervit HR, Whittingham DG and Rowson LER (1972) Successful culture in vitro of sheep and cattle ova Journal of Reproduction and Fertility 30 493497

Thompson JGE, Simpson AC, Pugh PA, Donnelly PE and Tervit HR (1990) Effect of oxygen concentration on in-vitro development of preimplantation sheep and cattle embryos Journal of Reproduction and Fertility 89 573-578

Tiffin GJ, Rieger D, Betteridge KJ, Yadav BR and King WA (1991) Glucose and glutamine metabolism in pre-attachment cattle embryos in relation to sex and stage of development Journal of Reproduction and Fertility 93 125-132

Tokumaru M, Goto K, Kajihara Y, Koba M, Nakanishi Y, Ogawa Y, Inohae S, Tasaki M, Oota H, Tateyama S and Kawabata T (1989) Methodological investigation on chromosomal preparation of bovine embryos - comparison of in vivo developed blastocysts and those obtained in culture after in vitro fertilization Japanese Journal of Zootechnical Science $60761-770$

Voelkel SA and Hu YX (1992) Effects of gas atmosphere on the development of one-cell bovine embryos in two culture systems Theriogenology 37 11171130

Whittingham DG (1971) Survival of mouse embryos after freezing and thawing Nature 233 125-126

Wright RW, Jr, Anderson GB, Cupps PT and Drost M (1976) Successful culture in vitro of bovine embryos to blastocyst stage Biology of Reproduction 14 $157-162$ 